\title{
Establishment of quantitative PCR methods for the quantification of geosmin-producing potential and Anabaena sp. in freshwater systems
}

\author{
Ming Su ${ }^{a}$, Virginie Gaget ${ }^{b, 1}$, Steven Giglio ${ }^{b, 2}$, Michael Burch ${ }^{b}$, Wei $\mathrm{An}^{a}$, Min Yang ${ }^{a, *}$ \\ a State Key Laboratory of Environmental Aquatic Chemistry, Research Center for Eco-Environmental Sciences, Chinese Academy of Sciences, \\ 18 Shuangqing Rd., Haidian, Beijing 100085, China \\ ${ }^{\mathrm{b}}$ South Australia Water Corporation, Australian Water Quality Centre, 250 Victoria Square, Adelaide, SA 5000, Australia
}

\section{A R T I C L E I N F O}

Article history:

Received 15 July 2012

Received in revised form

14 March 2013

Accepted 20 March 2013

Available online 6 April 2013

Keywords:

Anabaena sp.

Quantitative PCR

Geosmin

rpoC $_{1}$ gene

Geosmin synthase gene

\begin{abstract}
A B S T R A C T
Geosmin has often been associated with off-flavor problems in drinking water with Anabaena sp. as the major producer. Rapid on-site detection of geosmin-producers as well as geosmin is important for a timely management response to potential off-flavor events. In this study, quantitative polymerase chain reaction ( $q P C R$ ) methods were developed to detect the levels of Anabaena sp. and geosmin, respectively, by designing two PCR primer sets to quantify the rpoC $_{1}$ gene (ARG) and geosmin synthase one (GSG) in Anabaena sp. in freshwater systems. The ARG density determined by QPCR assay is highly related to microscopic cell count $\left(r^{2}=0.726, p<0.001\right)$, and the limit of detection (LOD) and limit of quantification (LOQ) of the qPCR method were $0.02 \mathrm{pg}$ and $0.2 \mathrm{pg}$ of DNA, respectively. At the same time, the relationship between geosmin concentrations measured by gas chromatography-mass spectrometry (GC-MS) and GSG copies was also established $\left(r^{2}=0.742\right.$, $p<0.001$ ) with similar LOD and LOQ values. Using the two qPCR protocols, we succeeded in measuring different levels of ARG and GSG copies in different freshwater systems with high incidence environmental substrata and diverse ecological conditions, showing that the methods developed could be applied for environmental monitoring. Moreover, comparing to the microscopic count and GC-MS analytical methods, the qPCR methods can reduce the time-to-results from several days to a few hours and require considerably less traditional algal identification and taxonomic expertise.
\end{abstract}

(c) 2013 Elsevier Ltd. All rights reserved.

\section{Introduction}

Cyanobacterial blooms occur frequently in lakes and reservoirs over the world and have exerted a serious impact on aquatic ecosystems, human health, and a large range of human activities (Battocchi et al., 2010). Such blooms are often accompanied with the occurrence of taste and odor problems caused by cyanobacterial metabolites such as geosmin (trans1,10-dimethyl-trans-9-decalol) and MIB (2-methylisoborneol or 1,2,7,7-tetramethyl-exo-bicyclo-[2,2,1]-heptan-2-ol) (Saadoun

\footnotetext{
* Corresponding author. Tel.: +86 106284 9175; fax: +86 1062923541.

E-mail addresses: ming.su@live.com (M. Su), Virginie.Gaget@sawater.com.au (V. Gaget), Steven.Giglio@healthscope.com.au (S. Giglio), mike.burch@sawater.com.au (M. Burch), anwei@rcees.ac.cn (W. An), yangmin@rcees.ac.cn (M. Yang).

${ }^{1}$ Current address: Ecology, Evolution and Landscape Sciences, School of Earth and Environment Sciences, Adelaide University, Adelaide, Australia.

${ }^{2}$ Current address: Healthscope Pathology SA, 1 Goodwood Rd., Wayville, SA 5034, Australia. 0043-1354/\$ - see front matter (c) 2013 Elsevier Ltd. All rights reserved.
} http://dx.doi.org/10.1016/j.watres.2013.03.043 
et al., 2001). Anabaena, a well-known bloom-forming cyanobacterial genus, has been reported to be responsible for $46 \%$ of geosmin-related taste and odor events (Kuosa, 1991; Krienitz et al., 2002; Sabour et al., 2005; Sotero-Santos et al., 2008). In 2007, a severe Anabaena bloom occurred in Yanghe Reservoir in north China, resulting in a serious water supply crisis due to the production of high concentration of geosmin (Li et al., 2010). Cyanobacteria grow exponentially forming blooms and forming large visible biomass within a short period of time. Moreover, cyanobacterial metabolites like geosmin are volatile and susceptible to biodegradation in water (Ho et al., 2007). Therefore a quick or even on-site detection method would be desirable during a taste and odor event, especially in the case of an extensive sampling (Battocchi et al., 2010). Microscopic count, which has long been the major approach used for the monitoring of algae in lakes and reservoirs (Hotzel and Croome, 1994), is very time-consuming (Rodenacker et al., 2001). In addition, the limitation of morphological identification criteria has sometimes rendered it difficult to assign cyanobacteria to a certain genus or species (Humbert et al., 2010), and the reliability of data depends largely on the skill and taxonomic expertise of the operators (Christensen et al., 2009). On the other hand, on-site detection of the odor compounds is generally not practicable as the equipment (usually gas chromatography-mass spectrophotometry (GC-MS)) used for this purpose are large machines and not transportable in the field (Deng et al., 2011).

Quantitative polymerase chain reaction (qPCR) has been proven to be reliable, robust, sensitive and fast (Rinta-Kanto et al., 2005; Rasmussen et al., 2008b), which may be suitable for the on-site survey of cyanobacterial blooms. In comparison with the 16S rRNA genes, which has been used extensively for the design of primers for cyanobacterial detection (Matsunaga et al., 2001; Rocap et al., 2002; Steindler et al., 2005), the gamma-unit of the DNA-dependent RNA polymerase $\left(\right.$ rpo $\left._{1}\right)$ gene could be a more discriminatory marker to assign cyanobacterial cultures/isolates at the genus or even the species levels (Bergsland and Haselkorn, 1991; Palenik and Haselkorn, 1992; Fergusson and Saint, 2000; Innok et al., 2005). This gene has been employed for rapid on-site monitoring of Cylindrospermopsis raciborskii by using qPCR in reservoirs (Marbun et al., 2012). With regard to geosmin, the geosmin synthase gene has been discovered recently, which is responsible for biosynthesis of geosmin in cyanobacteria. It has provided the fundamental knowledge to investigate into the relationship between geosmin production potential and geosmin synthase gene (GSG) expression (Cane and Watt, 2003; Gust et al., 2003; Cane et al., 2006; Jiang et al., 2006, 2007; Giglio et al., 2008). Moreover, the growth conditions affecting the expression of GSG in Anabaena circinalis have been examined (Giglio et al., 2011). These two genes would be good candidates for the development of specific PCR assays for the detection of Anabaena sp. and also other potential geosmin producers in the environment.

In this study, two PCR primer sets were designed to amplify a fragment of the Anabaena rpoC $_{1}$ gene (ARG) and GSG homologs, respectively. The specificities of the rpo $_{1}$-based primer set (ARG primers) and geosmin synthase gene based primer set (GSG primers) were verified by testing 47 and 11 cyanobacterial cultures, respectively. Both PCR assays were validated with a culture-based experiment using a geosmin-producing strain (A. circinalis AWQC-ANA318) over a period of 72 days, as well as 63 field samples ( 7 sites $\times 3$ repeats $\times 3$ levels) spiked with different levels of Anabaena (Anabaena spiroides FADC0001). This study provides a valuable on-site technique for the early monitoring of geosmin-producing Anabaena.

\section{Materials and methods}

\subsection{Cyanobacterial cultures}

Thirty Anabaena strains, fifteen Microcystis strains and two Cylindrospermopsis strains obtained from Australian Water Quality Centre (AWQC), Freshwater Algae Culture Collection of the Institute of Hydrobiology (FACHB) and Chinese Research Academy of Environmental Sciences (CRAES) were used to test the specificity of ARG primers (Table 1, the AWQCstrains were performed in AWQC in 2009, while the FACHB/ FADC-strains were performed in Beijing in 2012); on the other hand, eleven Anabaena strains were used to test the specificity of GSG primers (Table 2). A. circinalis strain AWQCANA318 was used to simulate a cyanobacterial bloom in a laboratory culture system. The strain was isolated at the AWQC in 1995 from a sample sourced from Pejar Dam in Goulburn, NSW, Australia, during a taste and odor episode (Giglio et al., 2011); In addition, A. spiroides strain FADC-0001 was used to validate the qPCR methods on field samples with A. spiroides supplemented. This strain was isolated at Chinese Research Academy of Environmental Sciences (CRAES) from Yanghe Reservoir in north China, during a cyanobacterial bloom in 2007. The reason for choosing these two strains was that they belong to the two major bloom-forming species in South Australia (SA) (Llewellyn et al., 2001) and China, respectively (Pan et al., 2009; Li et al., 2010).

The AWQC-ANA318 strain was grown under continuous illumination (2500 lux) for 72 days at $25^{\circ} \mathrm{C}$ without agitation in two crystal plastic containers $10 \mathrm{~L}$, Nalgene) in ASM-1 medium (Provasoli et al., 1957), and the initial cell density of the two cultures were at 1277 and 6436 cells $\mathrm{mL}^{-1}$, respectively. The cultures were sampled every 2-8 days for cell enumeration under light microscopy, geosmin analysis by GC-MS and DNA extraction for qPCR assays (the sampling was performed every 2 or 3 days in the lag phase and log phase, and the frequency decreased in the other phases; the longest interval was 8 days). On the other hand, the FADC-0001 strain was initially grown in BG-11 medium under continuous illumination for one week (Rippka et al., 1979), and subsequently added to the field samples collected from 5 freshwater ponds and 2 rivers in Beijing for qPCR applicability validation.

\subsection{Field sites, sampling and cell enumeration}

In order to assess the impact of biomass and particles in water on the quantification of ARG and GSG by qPCR, 5 freshwater aquaculture ponds (Weiming Lake (WML), Forest Park (FP), Yuyuantan (YYT), Houhai (HH) and Lotus Ponds (LP)) and 2 rivers (Wenyu River (WYR) and Qing River (QR)) spreading over 5 districts in Beijing, China were chosen (Fig. A.1). The pH, conductivity and salinity were determined on-site using a YSI 
Table 1 - Specificity of ARG primers (AN03/06).

\begin{tabular}{|c|c|c|c|}
\hline Strain & Genus/species & Sig. ${ }^{a}$ & Source \\
\hline FACHB-170 & Anabaena cylindrica & $++^{\mathrm{b}}$ & FACHB \\
\hline FACHB-190 & Anabaena azollae & $-^{c}$ & FACHB \\
\hline FACHB-245 & Anabaena flos-aquae & ++ & FACHB \\
\hline FACHB-251 & Anabaena sphaerica & + & FACHB \\
\hline FACHB-319 & Anabaena variabilis & - & FACHB \\
\hline FACHB-362 & Anabaena catenula & $+^{*}$ & FACHB \\
\hline FACHB-380 & Anabaena inaequalis & $+^{*}$ & FACHB \\
\hline FACHB-1096 & Cylindrospermopsis sp. & - & FACHB \\
\hline FACHB-1194 & Anabaena eucompacta & $+^{*}$ & FACHB \\
\hline FACHB-1199 & Anabaena eucompacta & - & FACHB \\
\hline FACHB-1219 & Anabaena sp. & $+^{*}$ & FACHB \\
\hline FACHB-1239 & Anabaena sp. & ++ & FACHB \\
\hline FACHB-1250 & Anabaena sp. & ++ & FACHB \\
\hline FACHB-1255 & Anabaena flos-aquae & ++ & FACHB \\
\hline FACHB-1263 & Anabaena flos-aquae & ++ & FACHB \\
\hline FADC-0001 & Anabaena spiroides & + & CRAES \\
\hline FADC-0002 & Microcystis sp. & - & CRAES \\
\hline AWQC-ANA318 & Anabaena circinalis & + & AWQC \\
\hline AWQC-ANA001 & Anabaena cylindrica & + & AWQC \\
\hline AWQC-ANA019 & Anabaena circinalis & + & AWQC \\
\hline AWQC-ANA025 & Anabaena oscillarioides & + & AWQC \\
\hline AWQC-ANA044 & Anabaena spiroides & + & AWQC \\
\hline AWQC-ANA048 & Anabaena affinis & + & AWQC \\
\hline AWQC-ANA049 & Anabaena circinalis & + & AWQC \\
\hline AWQC-ANA051 & Anabaena flos-aquae & + & AWQC \\
\hline AWQC-ANA056 & Anabaena spiroides & + & AWQC \\
\hline AWQC-ANA059 & Anabaena circinalis & + & AWQC \\
\hline AWQC-ANA217 & $\begin{array}{l}\text { Anabaena } \\
\text { aphanizomendoides }\end{array}$ & + & AWQC \\
\hline AWQC-ANA249 & Anabaena inaequalis & + & AWQC \\
\hline AWQC-ANA283 & Anabaena bergii & - & AWQC \\
\hline AWQC-ANA357 & Anabaena azollae & - & AWQC \\
\hline AWQC-ANA374 & Anabaena planktonica & + & AWQC \\
\hline AWQC-MIC005 & Microcystis aeruginosa & - & AWQC \\
\hline AWQC-MIC013 & Microcystis aeruginosa & - & AWQC \\
\hline AWQC-MIC017 & Microcystis aeruginosa & - & AWQC \\
\hline AWQC-MICO29 & Microcystis aeruginosa & - & AWQC \\
\hline AWQC-MIC034 & Microcystis aeruginosa & - & AWQC \\
\hline AWQC-MIC040 & Microcystis aeruginosa & - & AWQC \\
\hline AWQC-MIC049 & Microcystis aeruginosa & - & AWQC \\
\hline AWQC-MIC311 & Microcystis aeruginosa & - & AWQC \\
\hline AWQC-MIC320 & Microcystis aeruginosa & - & AWQC \\
\hline AWQC-MIC051 & Microcystis flos-aquae & - & AWQC \\
\hline AWQC-MIC053 & Microcystis flos-aquae & - & AWQC \\
\hline AWQC-MIC054 & Microcystis flos-aquae & - & AWQC \\
\hline AWQC-MIC055E & Microcystis flos-aquae & - & AWQC \\
\hline AWQC-MIC058 & Microcystis flos-aquae & - & AWQC \\
\hline AWQC-CYL001 & $\begin{array}{l}\text { Cylindrospermopsis } \\
\text { raciborskii }\end{array}$ & - & AWQC \\
\hline
\end{tabular}

a The gel results of amplifications using conventional PCR with ARG primers AN03/06.

b + , positive result; $+^{*}$, the gel showed weak signal; ++ , gel showed strong signal.

c The ARG primers didn't amplify the DNA.

probe (YSI6600, USA). In total, 63 water samples $(7$ sites $\times 3$ levels $\times 3$ repeats) were taken from the surface water $(0.5 \mathrm{~m})$ at each site. All field samples were supplemented with different concentrations (range from $10^{6}-10^{8}$ cells $\mathrm{L}^{-1}$ ) of the FADC0001 strain before analysis. Together with 32 culture samples collected from the laboratory culture system, all samples were used for cell enumeration, geosmin determination and DNA extraction.
Table 2 - Specificity of GSG primers (173AF/AR).

\begin{tabular}{llcc} 
Strain & Genus/species & Sig. $^{\mathrm{a}}$ & $\begin{array}{c}\text { Geosmin }^{\mathrm{b}} \\
\left(\mathrm{ng} \mathrm{L}^{-1}\right)\end{array}$ \\
\hline AWQC-ANA044 & Anabaena spiroides & + & 1.97 \\
AWQC-ANA102 & Anabaena flos-aquae & + & 4.05 \\
AWQC-ANA196 & Anabaena circinalis & + & 472.16 \\
AWQC-ANA328 & Anabaena circinalis & + & 204.36 \\
FACHB-1199 & Anabaena eucompacta & - & $<$ LOD $^{\mathrm{c}}$ \\
FACHB-1219 & Anabaena sp. & - & $<$ LOD $^{-}$ \\
FACHB-1239 & Anabaena sp. & + & 8270 \\
FACHB-1250 & Anabaena sp. & - & $<$ LOD \\
FACHB-1255 & Anabaena sp. & - & $<$ LOD \\
FACHB-1263 & Anabaena flos-aquae & - & $<$ LOD \\
FADC-0001 & Anabaena spiroides & + & 305.1 \\
Positive control & Nostoc sp. & + & $+^{\mathrm{d}}$ \\
Negative control & Milli-Q water & - & $0.09^{\mathrm{e}}$ \\
\hline
\end{tabular}

a Conventional PCR used GSG primers 173AF/AR; the melting temperature $\left(T_{\mathrm{m}}\right)$ corresponding to the target amplicon is $83^{\circ} \mathrm{C}$ for Anabaena species and $86^{\circ} \mathrm{C}$ for Nostoc species.

$\mathrm{b}$ The concentration of geosmin produced by the strains was measured by GC-MS.

c The geosmin concentration determined by GC-MS method is under the limit of detection (LOD).

d The positive control has been previously controlled for the production of geosmin and was found positive with a different melting temperature of $86^{\circ} \mathrm{C}$.

e There was residual geosmin in the water serving for analysis ( $0.09 \mathrm{ng} \mathrm{L}^{-1}$ ), thus for the strains for which the level of geosmin detected were around $1 \mathrm{ng} \mathrm{L}^{-1}$ is not possible to confirm true positive from negative.

Subsamples for cell enumeration were preserved with Lugol's iodine to a final concentration of 5\% (Sherr and Sherr, 1993) and then kept in dark until cell counting. The algal cell density was determined by the Utermöhl technique using a Sedgewick-Rafter counting chamber under a Nikon Eclipse 50i microscope with phase contrast and bright field illumination (Hasle, 1978). A magnification of $160 \times$ and $400 \times$ was used to identify and enumerate the cells, respectively. For each sample, triplicates of $1 \mathrm{~mL}$ each culture were collected and counted separately.

\subsection{Geosmin analysis}

Filtration through poly-carbonate filters was used to separate the dissolved from the intracellular geosmin fraction of all samples. Subsamples for dissolved geosmin determination were passed through a poly-carbonate membrane $(3 \mu \mathrm{m}$ pore size, $47 \mathrm{~mm}$ diameter, Millipore, Bedford, Mass) applying a vacuum (quantify under $40 \mathrm{kPa}$ ); while unfiltered sample represent the total geosmin. Both filtered and unfiltered fractions were stored in light-blocking bottles with airtight stopper supplemented with $\mathrm{HgCl}_{2}$ to a final concentration of $10 \mathrm{mg} \mathrm{L}^{-1}$ to prevent biodegradation (Li et al., 2010), and then analyzed within $24 \mathrm{~h}$ using the solid phase micro-extraction (SPME) method coupled with gas chromatography-mass spectrometry (GC-MS) (Agilent 6890/5975, Agilent Tech., USA) (Liang et al., 2005; Deng et al., 2011). Intracellular geosmin concentrations were calculated by subtracting dissolved geosmin from the total geosmin values. 


\subsection{DNA extraction}

Subsamples for genomic DNA extraction from both culture and field samples were filtered through a $5 \mu \mathrm{m}$ hydrophilic Durapore filter (Millipore, Bedford, Mass) until the filtration pads were saturated. The filters were then placed into a sterile tube (Axygen, USA) with $180 \mu \mathrm{L}$ of lysis buffer (DNeasy Kit 69504, Qiagen, Australia), and the cells were then broken using an ultrasonic peen with 6 cycles of $15 \mathrm{~s}$ on and $10 \mathrm{~s}$ off at $20 \%$ power (DIGITAL Sonifier S-250D, Branson, Dabury, USA). Additionally, to optimize cell lysis, $10 \mu \mathrm{L}$ of lysozyme solution (90 $\mathrm{mg} \mathrm{mL}^{-1}$, Invitrogen, USA) and $10 \mu \mathrm{L}$ proteinase $\mathrm{K}$ (DNeasy Kit 69504, Qiagen, Australia) were added to the cell preparation, and placed for incubation at $56^{\circ} \mathrm{C}$ for $3 \mathrm{~h}$. Finally, DNA extraction was completed using the DNeasy Blood \& Tissue Kit (Qiagen, USA) following the protocol provided by the manufacturer. The purity of the extracted DNA varied from 1.7 to 1.9 was assessed by calculating the ratio of the absorbance measured at $260 \mathrm{~nm}$ (A260) to the absorbance measured at $280 \mathrm{~nm}$ (A280), using NanoDrop1000 spectrophotometer version 3.2.1 software (Biolab).

\subsection{Primers design and specificity evaluation}

For the general detection of Anabaena populations and their geosmin production potential, two qPCR primer sets were designed which respectively amplify specific fragments of the $r_{p o C_{1}}$ gene coding for the gamma subunit of the RNA polymerase of Anabaena sp. and geosmin synthase gene responsible for the biosynthesis of geosmin in cyanobacteria. The sequences are as follows: ARG forward primer AN03 (5'TGTGGCTCATGTTTGGTATCTC-3') and reverse primer AN06 (5'-CCAATACCCACTTCCACACC-3'); GSG forward primer 173AF (5'-TGTGAGTACCCAAGAGG-3') and 173AR (5'CTGCCAATCCTGAAGTCCTTT-3') (Giglio et al., 2011).

As shown in Table 1, thirty Anabaena strains, fifteen Microcystis strains and two Cylindrospermopsis strains were used to test the specificity of the ARG primer set with conventional PCR coupled with gel electrophoresis (agarose 1\% v/ v). At the same time, eleven Anabaena strains were used to verify the specificity of the GSG primer set; in addition, a melting curve analysis, which was developed in 1990s and has been used to distinguish different PCR products based on GC/ AT ratio, length and sequence recently (Ririe et al., 1997; Rasmussen et al., 2007), was run at the end of qPCR runs to verify the melting temperature $\left(T_{m}\right)$ of the amplicons for the four AWQC strains (AWQC-ANA044/102/196/328). The $T_{m}$ corresponding to the target amplicon is $83{ }^{\circ} \mathrm{C}$ for Anabaena species and $86^{\circ} \mathrm{C}$ for the positive control of Nostoc sp. So only the samples showed a unique peak at the right temperature $\left(83^{\circ} \mathrm{C}\right.$ ) were considered as positive (Table 2). The $25 \mu \mathrm{L}$ PCR mixture included $1 \times$ PCR buffer (Takara, Dalian, China), $0.2 \mu \mathrm{L}$ dNTPs (Takara, Dalian, China), 1.25 U of Taq DNA polymerase (Takara, Dalian, China), $0.2 \mu \mathrm{M}$ of each primer (AN03/06 for ARG qPCR assay, 173AF/AR for GSG qPCR assay) and $2 \mu \mathrm{L}$ of template DNA. The amplification conditions were as follows: an initial denaturation step of $95^{\circ} \mathrm{C}$ for $5 \mathrm{~min}$, followed by 35 cycles of $95^{\circ} \mathrm{C}$ for $30 \mathrm{~s}, 50^{\circ} \mathrm{C}$ for $30 \mathrm{~s}$, and $72{ }^{\circ} \mathrm{C}$ for $30 \mathrm{~s}$, and a final extension step of $72^{\circ} \mathrm{C}$ for $10 \mathrm{~min}$. The PCR products were then used to run gel electrophoresis.

\subsection{Standards for qPCR analysis and qPCR protocol}

The DNA extracted from two strains AWQC-ANA318 and FADC-0001 were used as standards for both qPCR assays. The standard curves were determined by correlation between target genes (copy number in one reaction) and threshold cycle $\left(C_{\mathrm{T}}\right)$ value in a ten-fold serial dilution of Anabaena DNA. The laboratory culture and field samples were subsequently qualified based on their $C_{T}$ values. Equation (1) is the calculation of Anabaena genome copy number $(\mathcal{N})$ in one qPCR reaction.

$$
\begin{aligned}
\mathcal{N}(\text { copy })= & \frac{N_{\mathrm{A}}\left(\text { copy mol }^{-1}\right) c_{\mathrm{DNA}}\left(\mathrm{ng} \mu \mathrm{L}^{-1}\right) v_{\mathrm{DNA}}(\mu \mathrm{L})}{\mathcal{L}(\mathrm{bp}) \mathcal{M}_{\mathrm{DNA}}\left(\mathrm{g} \mathrm{mol}^{-1} \mathrm{bp}^{-1}\right)} \\
& \times 10^{-9}\left(\mathrm{~g} \mathrm{ng}^{-1}\right)
\end{aligned}
$$

In this equation, $N_{A}$ represents Avogadro constant, $c_{D N A}$ represents the DNA template concentration in $\mathrm{ng} \mu \mathrm{L}^{-1}, v_{\mathrm{DNA}}$ represents the DNA template volume in one qPCR reaction, $\mathscr{L}$ represents the Anabaena genome length in base pair (bp) and $\mathscr{M}_{\text {DNA }}$ represents the molecular mass of $1 \mathrm{bp}$ dsDNA. In this study, the calculations are based on a genome size of $4.5 \mathrm{Mb}$ bp for Anabaena sp. (Moustafa et al., 2009), and single copy ARG and GSG present in one Anabaena genome (Xie et al., 1989; Bergsland and Haselkorn, 1991).

The qPCR reactions were performed on four replicates using a Rotor-Gene Q instrument (Qiagen, Venlo, Netherlands). Each qPCR reaction was performed in $25 \mu \mathrm{L}$ which consisted of $1.5 \mathrm{mM} \mathrm{MgCl}_{2}$ (Invitrogen, USA), $1 \times \mathrm{PCR}$ buffer (Invitrogen, USA), $0.2 \mathrm{mM}$ dNTPs (Invitrogen, USA), $0.2 \mu \mathrm{M}$ of each primer (AN03/06 for ARG qPCR, 173AF/AR for GSG qPCR), $1 \mathrm{U}$ of Platinum Taq DNA polymerase (Invitrogen, USA), $2 \mu \mathrm{L}$ of template DNA, and $2.5 \mu \mathrm{M}$ SYTO9 (Invitrogen, USA). The amplification conditions were as follows: an initial denaturation step of $95^{\circ} \mathrm{C}$ for $5 \mathrm{~min}$, followed by 45 cycles of $95{ }^{\circ} \mathrm{C}$ for $30 \mathrm{~s}, 52{ }^{\circ} \mathrm{C}$ for $30 \mathrm{~s}$, and $72{ }^{\circ} \mathrm{C}$ for $30 \mathrm{~s}$, and a final extension step of DNA melting analysis from $75{ }^{\circ} \mathrm{C}$ to $95{ }^{\circ} \mathrm{C}$, with data being acquired every degree with a $10 \mathrm{~s} \mathrm{hold} \mathrm{at} \mathrm{each}$ step. All data were acquired on the "FAM3" channel, with excitation at $470 \mathrm{~nm}$ and emission at $510 \mathrm{~nm}$.

\subsection{Statistics}

The log-log regression, t-test, ANOVA and the figures in this study were performed using the R 2.13.1 system for statistical analysis (R Development Core Team, 2011).

\section{Results and discussion}

\subsection{Applicability of the designed primers}

In order to evaluate the specificity of the AN03/06 primers, genomic DNA from 30 Anabaena strains and 17 other strains was firstly amplified by conventional PCR. Gel electrophoresis was performed for all the amplification products to verify the length of the amplicons. Five Anabaena strains (FACHB-190, FACHB-319, FACHB-1199, AWQC-ANA283, AWQC-ANA357) belonging to Anabaena azollae, Anabaena variabilis, Anabaena eucompacta and Anabaena bergii failed to give positive amplifications, while all the other Anabaena strains showed positive 
results with a single band at the right size around 200 bp (only the gel electrophoresis results of FACHB-collections and FADC-collections are shown in Fig. A.2), although the bands of four strains (FACHB-362 Anabaena catenula, FACHB-380 Anabaena inaequalis, FACHB-1194 A. eucompacta and FACHB-1219 A. sp.) were relatively weak on gel. On the other hand, no amplification product was observed for Microcystis strains and Cylindrospermopsis strains (Table 1). The results imply that the ARG primers are capable of amplifying most Anabaena species. It should be noted that, the $\operatorname{rpoC}_{1}$ gene of three frequently reported bloom-forming species of A. circinalis (strain AWQCANA318), A. spiroides (strain FADC-0001) and Anabaena flosaquae could be well amplified by the ARG primers.

As shown in Table 2, six of 11 Anabaena strains possessing geosmin producing potentials $\left(1.97-8270 \mathrm{ng} \mathrm{L^{-1 }}\right.$ ) exhibited positive PCR results on gel electrophoresis, while the other 5 strains showing no geosmin producing potential (less than $1.0 \mathrm{ng} \mathrm{L}^{-1}$ ) exhibited negative results (only the results of FACHBcollections and FADC-0001 are shown in Fig. A.3). In addition, the melting curve analysis results exhibited distinct different in the melting temperatures $\left(\mathrm{T}_{\mathrm{m}}\right)$ between the amplicon of Nostoc sp. $\left(86^{\circ} \mathrm{C}\right)$ and those of the four AWQC Anabaena strains $\left(83^{\circ} \mathrm{C}\right)$, showing that the melting analysis may also be used for differentiating the Anabaena species between each other. Overall, the GSG primers are capable of amplifying the geosmin synthesis genes of the Anabaena species by coupling with melting curve analysis, and that could be used as a potential tool for geosmin detection in natural water bodies.

In 2003 a sesquiterpene protein domain in Streptomyces coelicolor A3(2) was linked to the presence of the taste and odor compound geosmin (Cane and Watt, 2003; Gust et al., 2003). Since then the gene responsible for the biosynthesis of geosmin (geo gene) has been extensively characterized (Cane et al., 2006; Jiang et al., 2006, 2007). In 2007 two geoA-like genes were detected in a strain of Phormidium (cyanobacteria, Oscillatoriales) (Ludwig et al., 2007) but their function in cyanobacteria were not elucidated until full characterization of the geoA gene was performed in Nostoc punctiforme (Giglio et al., 2008). Since then the expression of these genes has been studied in a single strain of Anabaena (Giglio et al., 2011), which was demonstrated that the expression of the geosmin gene appears to be constitutive in nature. While in recent years some studies established quantitative PCR assays to detect and measure the production of geosmin by Streptomycetes in the environment (Auffret et al., 2011; Lylloff et al., 2012); to the best of our knowledge, no peer reviewed study has displayed a quantitative PCR assay to detect the production of geosmin specifically by cyanobacteria. The present study is the first qPCR assays for the detection and quantification of the cyanobacterial geosmin synthase in waters. Moreover, the ARG qPCR assay allows the detection of several Anabaena species, major bloom-forming genus and confirmed geosmin producers. Combined, these two assays allow the monitoring of the population of Anabaena at the same time as the production of geosmin. The comparison of the two results therefore assists in determining if Anabaena is responsible for the release of geosmin in the environment.

\subsection{Validation of the qPCR assays}

The limit of detection (LOD) and limit of quantification (LOQ) of both ARG and GSG qPCR assays were obtained by testing the 10 fold serial dilutions of AWQC-ANA318 genomic DNA range from $0.02 \mathrm{pg}$ (approx. 4 genome copy) to $2.0 \times 10^{4} \mathrm{pg}$ (approx. $4 \times 10^{6}$ genome copy) DNA in one qPCR reaction. As shown in Table 3 , the standard errors of $C_{T}$ values were increasing along

Table 3 - The limit of detection (LOD) and limit of quantification (LOQ) of ARG and GSG qPCR assays.

\begin{tabular}{|c|c|c|c|c|c|c|c|}
\hline & $\begin{array}{l}\text { DNA quantity } \\
\text { target }^{\mathrm{a}}(\mathrm{pg})\end{array}$ & $\mathrm{C}_{\mathrm{T}}$ target $^{\mathrm{b}}$ & $\begin{array}{c}\text { DNA quantity } \\
\text { target qPCR }{ }^{\mathrm{c}, \mathrm{b}} \\
\text { (gene copy number) }\end{array}$ & CV (\%) & $\begin{array}{c}\% \text { Positive } \\
\text { samples }\end{array}$ & $\begin{array}{c}\text { Lower } \\
\text { than LOD? }\end{array}$ & $\begin{array}{c}\text { Lower } \\
\text { than LOQ?e }\end{array}$ \\
\hline \multirow{7}{*}{ ARG assay ${ }^{\mathrm{f}}$} & 2.00E-02 & $34.7 \pm 0.63$ & $4.34 \mathrm{E}+00 \pm 1.82$ & $42 \%$ & $94 \%$ & No & Yes \\
\hline & 2.00E-01 & $31.4 \pm 0.32$ & $3.95 \mathrm{E}+01 \pm 0.99$ & $25 \%$ & $100 \%$ & No & No \\
\hline & $2.00 \mathrm{E}+00$ & $28.0 \pm 0.18$ & $3.80 \mathrm{E}+02 \pm 0.51$ & $13 \%$ & $100 \%$ & No & No \\
\hline & $2.00 \mathrm{E}+01$ & $24.4 \pm 0.1$ & $4.65 \mathrm{E}+03 \pm 0.31$ & $7 \%$ & $100 \%$ & No & No \\
\hline & $2.00 \mathrm{E}+02$ & $21.6 \pm 0.15$ & $3.28 \mathrm{E}+04 \pm 0.36$ & $11 \%$ & $100 \%$ & No & No \\
\hline & $2.00 \mathrm{E}+03$ & $18.0 \pm 0.14$ & $3.93 E+05 \pm 0.38$ & $10 \%$ & $100 \%$ & No & No \\
\hline & $2.00 \mathrm{E}+04$ & $15.0 \pm 0.09$ & $3.15 \mathrm{E}+06 \pm 0.19$ & $6 \%$ & $100 \%$ & No & No \\
\hline \multirow[t]{7}{*}{ GSG assay ${ }^{g}$} & $2.00 \mathrm{E}-02$ & $37.7 \pm 0.37$ & $4.35 E+00 \pm 1.20$ & $28 \%$ & $96 \%$ & No & Yes \\
\hline & 2.00E-01 & $34.6 \pm 0.22$ & $3.79 \mathrm{E}+01 \pm 0.66$ & $17 \%$ & $100 \%$ & No & No \\
\hline & $2.00 \mathrm{E}+00$ & $31.2 \pm 0.16$ & $4.10 \mathrm{E}+02 \pm 0.45$ & $11 \%$ & $100 \%$ & No & No \\
\hline & $2.00 \mathrm{E}+01$ & $27.9 \pm 0.05$ & $4.08 \mathrm{E}+03 \pm 0.14$ & $3 \%$ & $100 \%$ & No & No \\
\hline & $2.00 \mathrm{E}+02$ & $24.7 \pm 0.08$ & $3.83 \mathrm{E}+04 \pm 0.22$ & $6 \%$ & $100 \%$ & No & No \\
\hline & $2.00 \mathrm{E}+03$ & $21.2 \pm 0.10$ & $4.51 \mathrm{E}+05 \pm 0.30$ & $7 \%$ & $100 \%$ & No & No \\
\hline & $2.00 \mathrm{E}+04$ & $18.3 \pm 0.05$ & $3.51 E+06 \pm 0.12$ & $4 \%$ & $100 \%$ & No & No \\
\hline
\end{tabular}

a Measured by spectrophotometry.

b Data are mean standard deviations.

c Determined by corresponding qPCR assay.

d A sample is under the limit of detection (LOD) when less than $90 \%$ of positive controls are showing significant fluorescence.

e A sample is under the limit of quantification (LOQ) when a coefficient of variation (CV) higher than $25 \%$ is observed.

$\mathrm{f}$ The Anabaena rpoC1 gene qPCR assay with the ARG primers AN03 and AN06.

$\mathrm{g}$ The geosmin synthase gene qPCR assay with the GSG primers 173AF and 173AR. 
with the fold number dilutions of DNA, which results in an increasing error of qPCR results. Over $90 \%$ of the DNA samples showed fluorescence signals for both assays at a DNA concentration over $0.02 \mathrm{pg}$ level; On the other hand, $25 \%$ or lower coefficient of variation (CV) of $C_{T}$ values were obtained at $0.2 \mathrm{pg}$ DNA level for both assays. Thus, the LOD and LOQ of both methods were $0.02 \mathrm{pg}$ DNA and $0.2 \mathrm{pg}$ DNA, respectively. The LOQ of $0.2 \mathrm{pg}$ is around 40 copy number of target gene in one reaction for both $\mathrm{QPCR}$ assays, suggesting that the methods are capable of determining low concentration of target genes in natural samples.

\subsection{Standard curves and linearity for the quantification} of Anabaena sp. and geosmin using qPCR

According to LOQ of both qPCR assays, the standard curves were constructed with 10 fold serial dilution of extracted genomic DNA from the AWQC-ANA318 strain and FADC-0001 strain (data not shown), respectively (Fig. 1). The range of DNA concentration in one reaction is from $0.2 \mathrm{pg}$ (40 copies) to $20 \mathrm{ng}\left(4.0 \times 10^{6}\right.$ copies) for ARG qPCR, and from $2 \mathrm{pg}$ (400 copies) to $20 \mathrm{ng}$ $\left(4.0 \times 10^{6}\right.$ copies $)$ for GSG qPCR assay. The following linear relationships between cycle threshold $\left(C_{\mathrm{T}}\right)$ and the log of the gene copies were obtained: $C_{\mathrm{T}}=-3.34 \log \rho_{\mathrm{p}}+36.65\left(r^{2}=0.999\right)$ with an efficiency of $99 \%$ for ARG qPCR assay and $C_{\mathrm{T}}=-3.27 \log \gamma_{\mathrm{p}}+$ $39.71\left(r^{2}=0.999\right)$ with an efficiency of $102 \%$ for GSG qPCR assay, respectively. These results proved that the two qPCR assays developed in this study are reliable for the quantification of Anabaena population and geosmin producing potential.

\subsection{Quantification of ARG and comparison with} microscopic count

Using DNA extracted from 32 AWQC-ANA318 culture samples from the laboratory simulated bloom, amplification results for
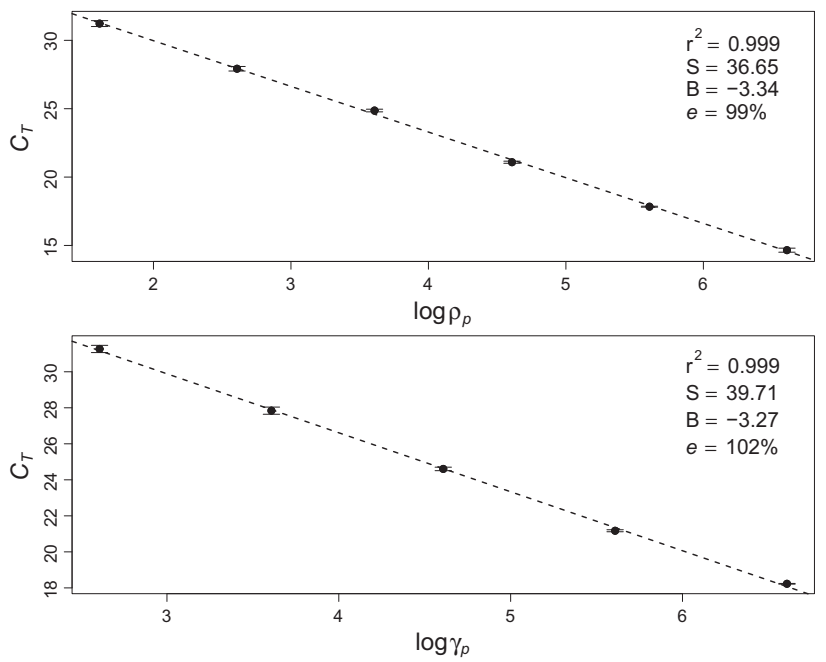

Fig. 1 - Standard curves for ARG (top) and GSG (bottom) by qPCR with 10 fold serial dilutions of AWQC-ANA318 cultures. $\rho_{\mathrm{p}}$ is the ARG copy numbers in one qPCR reaction, and $C_{T}$ is the cycle threshold of $q P C R$ amplifications. Error bars stand for the standard deviations (SD) from four independent amplifications ( $r$, correlation coefficient; $S$, regression slope; $B$, intercept; $e$, amplification efficiencies). the ARG qPCR assay were compared to cell density determined by microscopic count.

\subsubsection{In vitro study}

Two independent AWQC-ANA318 cultures named AE1 and AE2 were used to simulate the Anabaena blooms in laboratory. The initial cell densities of the two cultures were 1.28

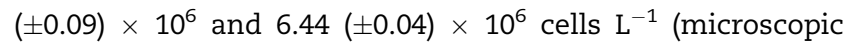
count), respectively (Fig. 2, solid line); the cultures were then kept in log-phase for three weeks, forming a bloom-like population. Though the concentrations of the two independent cultures were initially different, the cell density showed no significant difference after 4 weeks $(p=0.13)$, when the stationary-phase started. From week 5 to week 8, both cultures showed a slight decrease of cell density; however, a second growth phase occurred for both cultures, most likely due to the release of the nutrients from dead cells.

During the simulated Anabaena bloom, the cell density of the AWQC-ANA318 cultures varied from approximately $1 \times 10^{6}-1 \times 10^{9}$ cells $L^{-1}$ (Fig. 2); on the other hand, the ARG concentrations, obtained by ARG qPCR assay, varied from $1 \times 10^{6}-1 \times 10^{11}$ copies $L^{-1}$. A positive log-log correlation was found between the data sets determined by the two different methods $\left(r^{2}=0.726, p<0.001\right)$, as shown in Equation (2).

$\log \left(\rho_{\mathrm{m}}\right)=0.6346 \log \left(\rho_{\mathrm{p}}\right)+1.919$

In this equation $\rho_{\mathrm{p}}$ and $\rho_{\mathrm{m}}$ represent respectively the Anabaena rpoC $_{1}$ gene density obtained from the qPCR method and the cell density determined by microscopic count. At the same time, the comparison was plotted in Fig. 3 (filled circle), where the thick solid line is the log-log regression line, and the two thin long dashed lines are the $99 \%$ confidence interval (CI).

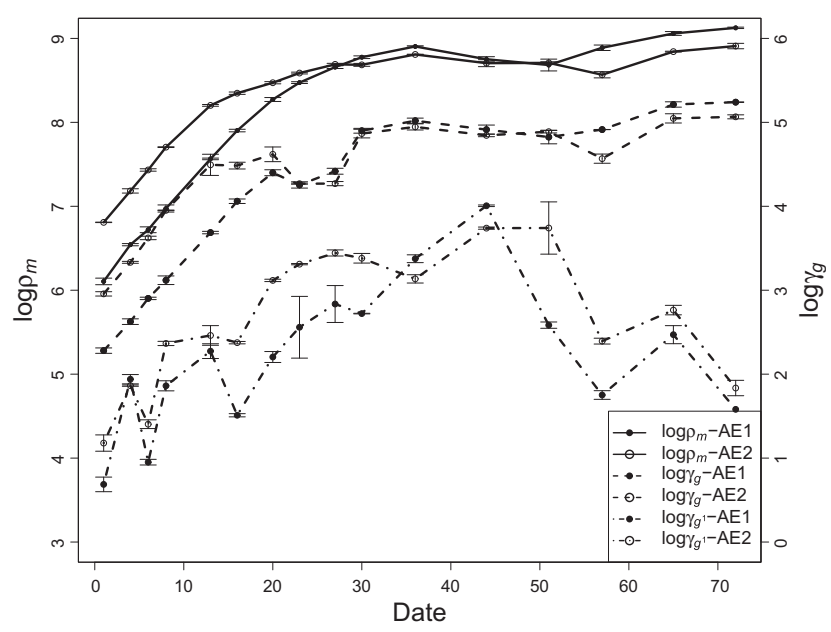

Fig. 2 - The cell density ( $\rho_{\mathrm{m}}$, solid lines) and geosmin concentration (intracellular geosmin, $\gamma_{g}$, dashed lines; extracellular geosmin, $\gamma_{g}^{\prime}$, dot-dashed lines) of two independent AWQC-ANA318 culture samples (AE1 $\bullet$ and AE2 $\left.{ }^{\circ}\right)$ during the cultivation. The values were obtained by microscopic count and GC-MS method. Error bars represent the standard deviations from 3 independent results for cell counts and two parallel samples for geosmin data. 


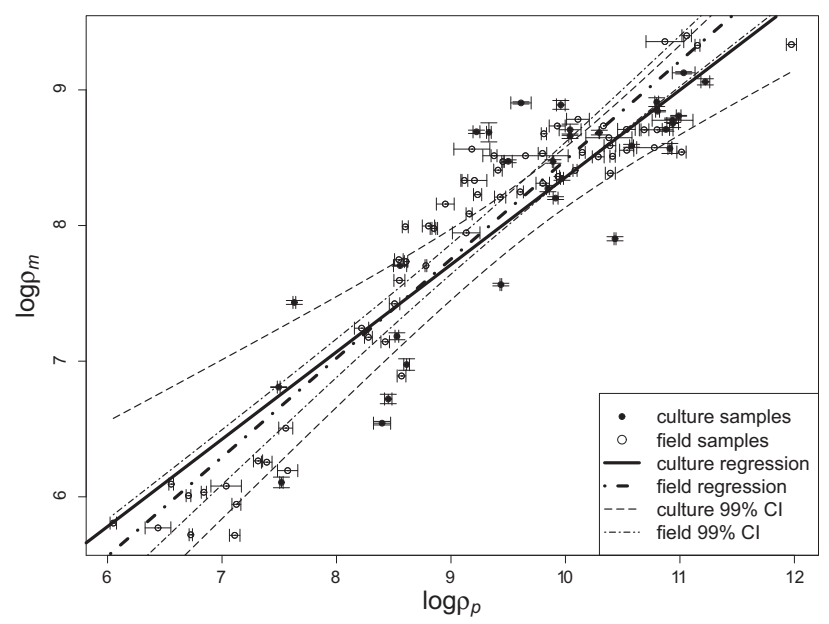

Fig. 3 - Comparison of the Anabaena cell density and ARG copy numbers. The data are 32 samples of AWQC-ANA318 strain from laboratory system $(\odot)$ and 63 field samples spiked with FADC-0001 strain from field freshwater system ( $\circ) . \rho_{\mathrm{p}}$ ( $x$-axis) is the ARG copy numbers determined by ARG qPCR assay, and $\rho_{\mathrm{m}}$ ( $y$-axis) is the Anabaena cell density obtained by microscopic count. Error bars stand for the standard deviation from 3 independent microscopic count data and 6 independent ARG copy numbers. The log-log regression lines are based on the comparison between $\rho_{\mathrm{m}}$ and $\rho_{\mathrm{p}}$ of culture samples (thick solid line) and field samples (thick dot-dashed line), and the curves are the $99 \%$ confident interval (CI) of the two regression lines (culture, thin dashed lines; field, thin dot-dashed lines).

According to the equation, approximately 5-100 ARG copies were present in one AWQC-ANA318 cell.

\subsubsection{Validation on field samples}

In order to evaluate the inhibition factor linked to the quality of field water samples, 63 field samples were tested using both methods; the samples were collected from 5 freshwater ponds and 2 rivers which showed greatly dissimilar physiochemical properties and ecological bio-community compositions. As shown in Table 4, QR showed the lowest $\mathrm{pH}$ level (6.71) and

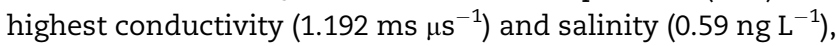
and contained diverse algal species with Fragilaria as the dominant one (Morales, 2005); $\mathrm{HH}$ exhibited the highest $\mathrm{pH}$ and low salinity and conductivity, and was dominated by Melosira, a filamentous diatom with thick cell walls; FP and LP exhibited high algal density and were dominated by Lyngbya, which could temporarily monopolize aquatic ecosystems when they form dense floating mats in water (Beer et al., 1986); WML was dominated by Pediastrum, a genus of green algae commonly present in freshwater microhabitats (Haas, 1996). Chlamydomonas, a genus of green algae consisting of unicellular flagellates (Harris et al., 1989), was dominant in YYT; and Euglena, a widely studied member of the phylum Euglenozoa (Cramer and Myers, 1952), was dominant in WYR. With regard to bio-community characteristics, only 4 species were observed in QR with a diversity index of 1.46; however, FP, LP, YYT and WML showed a much higher Richness index (Colwell, 2009) around 20, while the diversity index (Shannon et al., 1949) varied from 1.35 to 10.62 , implying a greatly dissimilar traits between sites.

The field samples were initially spiked with different concentrations of FADC-0001 cells, then the cell density was determined by microscopic count, and the ARG density was obtained by ARG qPCR assay. An analysis of variance (ANOVA) was performed to evaluate the effects of the background biomass. $\iota_{1}\left(=\log \left(\rho_{\mathrm{p}} / \rho_{\mathrm{m}}\right)\right)$ is logarithmic ARG copy density normalized by cell density, the mean $\iota_{1}$ of each site are in the range of $1.17(\mathrm{FP})$ to $1.54(\mathrm{QR})$, and the ANOVA result showed no significant difference between the sites $(F=1.003, p=0.43$, Fig. A.4). The evaluation of the effect from the cell density on amplification was performed using the ANOVA; the samples were grouped by 3 levels $\left(\mathrm{L}_{1}\right.$ : bottom $1 / 3,<8.0 \times 10^{7}$ cells $\mathrm{L}^{-1}$, $\mathrm{L}_{2}$ : middle $1 / 3,<3.3 \times 10^{8}$ cells $\mathrm{L}^{-1}$ and $\mathrm{L}_{3}$ : top $1 / 3$, $<3.0 \times 10^{9}$ cells $\mathrm{L}^{-1}$ ) of FADC-0001 cell density, showing no significant difference between $\mathrm{L}_{1}$ and $\mathrm{L}_{2}(F=1.614, p=0.212)$,

\section{Table 4 - The physicochemical properties and ecological bio-community compositions of field sampling sites.}

\begin{tabular}{|c|c|c|c|c|c|c|c|c|c|}
\hline Site & $\begin{array}{l}\text { Depth } \\
\text { (m) }\end{array}$ & $\begin{array}{l}\text { Salinity } \\
\left(\text { ng L L }^{-1}\right)\end{array}$ & $\mathrm{pH}$ & $\begin{array}{l}\text { Conductivity } \\
\left(\mathrm{ms} \mu \mathrm{s}^{-1}\right)\end{array}$ & $\begin{array}{l}\text { Algal density } \\
\text { (cells L }{ }^{-1} \text { ) }\end{array}$ & $\begin{array}{l}\text { Dominant } \\
\text { genus }\end{array}$ & Other present genera & $R^{a}$ & $\mathrm{~S}-\mathrm{W}$ index ${ }^{\mathrm{b}}$ \\
\hline WML & $<5$ & 0.29 & 7.14 & 0.598 & $8,925,000$ & Pediastrum & $\begin{array}{l}\text { Chlorococcales, Synedra, } \\
\text { Scenedesmus, Diatoma, etc. }\end{array}$ & 18 & 6.44 \\
\hline FP & $<3$ & 0.29 & 7.14 & 0.598 & $461,100,000$ & Lyngbya & $\begin{array}{l}\text { Synedra, Scenedesmus, } \\
\text { Merismopedia, Selenastrum, etc. }\end{array}$ & 22 & 1.99 \\
\hline YYT & $<4$ & 0.2 & 7.09 & 0.414 & $9,390,000$ & Chlamydomonas & $\begin{array}{l}\text { Cyclotella, Scenedesmus, } \\
\text { Melosira, Diatoma, etc. }\end{array}$ & 19 & 10.62 \\
\hline $\mathrm{HH}$ & $<2$ & 0.2 & 7.82 & 0.42 & $2,600,000$ & Melosira & $\begin{array}{l}\text { Diatoma, Cyclotella, Pediastrum, } \\
\text { Scenedesmus, etc. }\end{array}$ & 16 & 8.41 \\
\hline LP & $<5$ & 0.39 & 7.25 & 0.797 & $301,700,000$ & Lyngbya & $\begin{array}{l}\text { Aphanocapsa, Merismopedia, } \\
\text { Scenedesmus, Pediastrum, etc. }\end{array}$ & 20 & 1.35 \\
\hline WYR & - & 0.41 & 7.53 & 0.834 & $4,701,000$ & Euglena & $\begin{array}{l}\text { Frustulia, Aphanizomenon, } \\
\text { Synedra, Cyclotella, etc. }\end{array}$ & 8 & 1.63 \\
\hline QR & - & 0.59 & 6.71 & 1.192 & $4,750,000$ & Fragilaria & Cyclotella, Scenedesmus, Melosira & 4 & 1.46 \\
\hline
\end{tabular}

a The Richness index, the number of genus/species per sample (Colwell, 2009).

b The Shannon-Weaver diversity index (Shannon et al., 1949). 
but significant difference between $\mathrm{L}_{1} / \mathrm{L}_{2}$ and $\mathrm{L}_{3}(F=13.7$, $p<0.01)$. The results indicate that the impact of the inhibition due to the background biomass was not the most important issue here, while Anabaena cell density should be taken into consideration to get a better estimation.

The compared data are shown in Fig. 3 (hollow circle), where the thick dot-dashed line is the log-log regression model, and the thin dot-dashed curves are the 99\% CI. The qPCR results were in agreement with microscopic count $\left(\log \rho_{\mathrm{m}}=0.7301 \log \rho_{\mathrm{p}}+1.181, r^{2}=0.906, p<0.001\right)$; furthermore, the regression line of field samples was consistent with that of culture sample, indicating that the ARG qPCR assay is a good potential tool to track down the Anabaena population in natural water bodies.

Previous studies have established qPCR methods for the quantification of algal cells in water with a correlation coefficient between 0.6 and 0.9 (Behets et al., 2007; Koskenniemi et al., 2007). In comparison, this study has used a larger sample set, and it provides a relatively high correlation coefficient, which could be attributed to the highly discriminatory $r_{p o C_{1}}$ gene providing sufficient sequence variation to assign more specifically cyanobacteria. Thus, the ARG qPCR assay represents a useful tool to track down Anabaena especially during a bloom episode.

\subsection{Quantification of GSG and comparison with the GC-MS results}

\subsubsection{Laboratory study}

The geosmin concentrations of two independent AWQCANA318 cultures are shown in Fig. 2 (intracellular geosmin: dashed line, extracellular geosmin: dotted line); the intracellular geosmin increased along with the bloom stage and cell density, while the extracellular geosmin concentration increased during the first 7 weeks, and then decreased to a very low level after 3 weeks. The intracellular geosmin concentrations of these cultures were in the range from $1 \times 10^{2}$ to $1 \times 10^{5} \mathrm{ng} \mathrm{L}^{-1}$, thus the GSG qPCR assay was valid for the quantification of geosmin production. However, most of geosmin (82.9\%-100.0\%, data shown in Table A.1) was present within the cells, which was consistent with previous reports (Wu and Jüttner, 1988; Zhang et al., 2009; Li et al., 2010; Giglio et al., 2011), thus the intracellular geosmin is more representative of the population growth and health.

On the other hand, the GSG density in culture samples was determined by GSG qPCR assay, which was then compared with the geosmin concentration measured by GC-MS. We found that the GSG density exhibited stronger correlation with the intracellular geosmin concentration $\left(r^{2}=0.742, p<0.01\right.$, Equation (3)) than extracellular geosmin $\left(r^{2}=0.253, p<0.01\right.$, Fig. A.6), possibly due to the rapid biodegradation of extracellular geosmin (Li et al., 2010).

$\log \left(\gamma_{g}\right)=0.664 \log \left(\gamma_{p}\right)-2.100$

In this equation $\gamma_{\mathrm{g}}$ represents the intracellular geosmin concentration obtained by GC-MS method in ng L $\mathrm{L}^{-1}$ and $\gamma_{\mathrm{p}}$ represents the GSG copy number obtained by qPCR method in copies $\mathrm{L}^{-1}$. Fig. 4 shows the comparison between GSG copy number $\left(\gamma_{p}, x\right.$-axis $)$ and intracellular geosmin

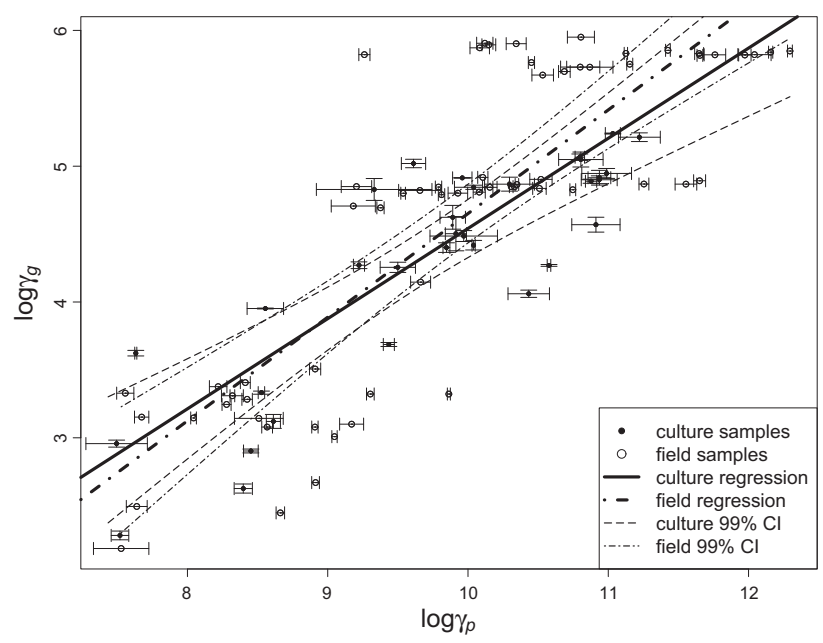

Fig. 4 - Quantification of GSG copy numbers $\left(\gamma_{p}, x\right.$-axis) by GSG qPCR assay and the relation with intracellular geosmin concentration $\left(\gamma_{g}, y\right.$-axis) determined by GC-MS method. The determined data are 32 culture samples of AWQC-ANA318 strain from laboratory system $(\bullet)$ and 63 field samples spiked with FADC-0001 strain from the field freshwater system ( $)$. Error bars stand for the standard deviations from 3 independent geosmin concentration data and 6 independent GSG copy numbers. The log-log regression is used to explain the relations between GSG copy numbers and intracellular geosmin concentration for culture samples (thick solid line) and field samples (thick dot-dashed line), the curves are the $99 \%$ confident interval (CI) of two regression lines (culture, thin dashed lines; field, thin dot-dashed lines).

concentration ( $\gamma_{g}, y$-axis) of the culture samples. According to the log-log model, the intracellular geosmin production potential was in the range of $1-40$ fg geosmin per copy GSG. Li et al. (2010) reported that the average geosmin production potential for A. spiroides cells during a bloom in 2007 was approximately

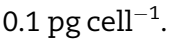

\subsubsection{Validation on field study}

The 63 field samples spiked with FADC-0001 cells were used to evaluate the applicability of GSG qPCR assay on environmental samples, by comparing the obtained results with geosmin concentration determined by GC-MS. Firstly, ANOVA was performed to analyze the impact of the background biomass. $\iota_{2}\left(=\log \left(\gamma_{\mathrm{g}} / \gamma_{\mathrm{p}}\right)\right)$ is the logarithmic geosmin production potential of single GSG copy, the mean $\iota_{2}$ of all sites are in the range of $4.96(\mathrm{QR})$ to 5.7 (WML, Fig. A.5), and the ANOVA showed no significant difference between the sites $(F=2.27, p=0.053)$.

Fig. 4 illustrates the comparison between the GSG copy numbers determined by qPCR and geosmin concentration; the results were significantly correlated $\left(\log \gamma_{\mathrm{g}}=0.763 \log \right.$ $\gamma_{p}-2.98, r^{2}=0.694, p<0.001$, thick dot-dashed line). Compared to culture samples (filled circle), the field samples (hollow circle) showed a wider distribution pattern. The highest intracellular geosmin was about $1 \times 10^{6} \mathrm{ng} \mathrm{L}^{-1}$, which is beyond the range of the culture samples and such 
concentration usually rarely occurs in natural waters; at this level, the GSG density showed a much higher variance than the geosmin concentration measured by GC-MS, which could be due to the inhibition caused by high concentration of DNA. As a follow-up research of the expression of GSG in A. circinalis (Giglio et al., 2011), this study provides justification for the use of the GSG qPCR method as a useful predictive tool to evaluate the geosmin production in fresh water.

\subsection{Methods applicability analysis}

Although the two qPCR assays exhibited the capabilities to estimate the Anabaena population level and geosmin concentration, respectively, relatively high variances were observed in qPCR assays in comparison with the traditional microscopic counting and GC-MS analysis methods, which could compromise the applicability of the qPCR assay methods. Therefore identifying the potential sources of variances is very important in this study. On one hand, the field samples were consistent with the culture samples, implying the inhibition by background biomass is not the major cause; on the other hand, there was very high consistency between the ARG and GSG densities in both the culture (Fig. 5 $r^{2}=0.9455, p<0.001$ ) and field samples (Fig. A.7), implying that the main variances are caused by DNA extraction other than the amplification process (since the two qPCR assays shared the sample DNA in this study). In addition, apart from the fact that inhibition is usually more important with high concentration of DNA in qPCR assays, the increased variability observed on the samples with high DNA concentration could be explained by the fact that the commercial DNA extraction kit used for this study was not well adapted for the extraction of samples with high density cells (the reason could be the variance of DNA concentration is strongly affected by operation steps of DNA extraction, while commercial DNA extraction kit usually has $10-20$ steps to get a high extraction efficiency, but also raises the variances greatly). Therefore, a

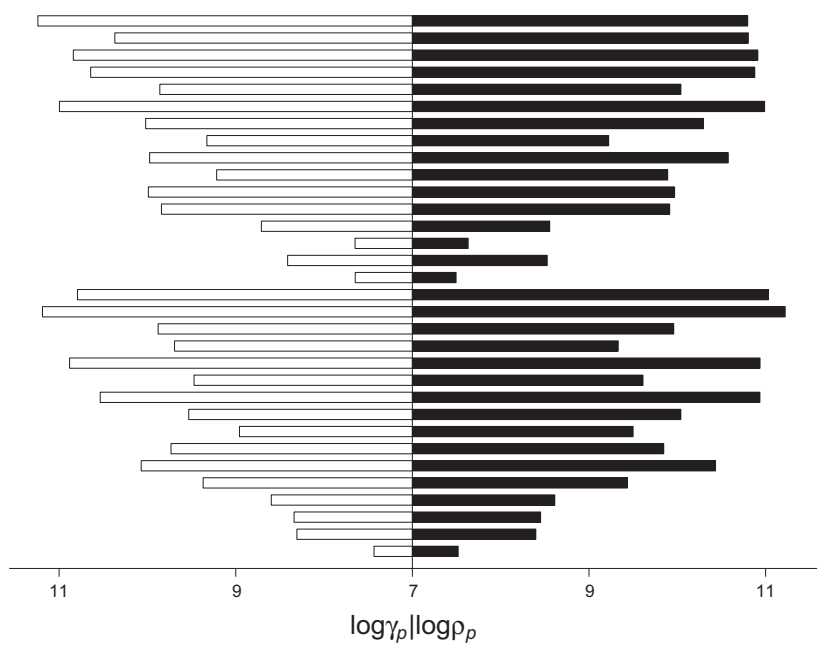

Fig. 5 - The qPCR variance analysis. The comparison of ARG (right) and GSG (left) copy numbers determined by ARG qPCR assay and GSG qPCR assay, respectively; the data are of the 32 culture samples from the laboratory system. simple (less steps) method for DNA extraction with relative lower efficiency is a potential solution. A microwave-based method has been shown to be promising for the extraction of cyanobacterial DNA for qPCR amplifications (Orsini and Romano-Spica, 2001; Rasmussen et al., 2008a); moreover, the two qPCR assays developed in the present study are capable of determining low concentration of DNA as they both have low LODs. Thus, the micro-based method would very likely be applicable in conjunction with the two qPCR assays.

Recent studies have shown that the qPCR assay could be used for the quantification of the toxic Microcystis sp. (RintaKanto et al., 2005), and cylindrospermopsin-producing cyanobacteria (Behets et al., 2007). In comparison with the approaches proposed in the previous studies, the method developed in this study allows the simultaneous detection of the Anabaena sp. and the geosmin-producing potential using the same qPCR protocol. This merit is very important since quantifying both the odor-causing algae and their odor production potential will be necessary during an odor episode caused by algae. In addition, the ARG and GSG primers are specific to the rpoC $_{1}$ gene and geosmin synthase gene, which are corresponding to amplify several important Anabaena species including A. circinalis, A. spiroides and A. flos-aquae etc., and Anabaena geosmin-producing potentials, respectively; besides, the LODs and LOQs were very low for both assays, making it possible to track down all Anabaena blooming stages even under the presence of abundant other algal species. Thus, the two assays represent a useful tool to evaluate the Anabaena population and its contribution to the release of geosmin in natural water.

\section{Conclusion}

The opportunity for rapid monitoring of potential geosminproducing Anabaena sp. could greatly improve the capacity for management of freshwater resources used for both drinking water supplies and other uses such as industry and aquaculture. The present work provided two qPCR assays able to identify Anabaena sp., a major taste and odor producing cyanobacteria as well as the geosmin synthase gene in freshwater system for the first time in a peer reviewed study. Both assays were proved to be reliable and showed a good correlation with cell density and geosmin concentration using microscope and GC-MS techniques, respectively. These two assays represent reliable new tools for the monitoring of geosmin-producing Anabaena populations.

\section{Acknowledgment}

We greatly thank CRAES for providing two strains FADC-0001 and FADC-0002 in this study. We would like to express our gratitude to the National Natural Science Foundation of China (50938007) and Sinotropia project (6002GJHZ1203), and the AWQC for their support during this study. We would like also to thank the Australian Department of Innovation, Industry, Science and Research for the funding of this work (funding agreement CH080202). 


\section{Appendix A. Supplementary data}

Supplementary data related to this article can be found at http://dx.doi.org/10.1016/j.watres.2013.03.043.

\section{R E F E R E N C E S}

Auffret, M., Pilote, A., Proulx, É., Proulx, D., Vandenberg, G., Villemur, R., 2011. Establishment of a real-time PCR method for quantification of geosmin-producing Streptomyces spp. in recirculating aquaculture systems. Water Research 45 (20), 6753-6762. URL: http://www.sciencedirect.com/science/ article/pii/S004313541100618X.

Battocchi, C., Totti, C., Vila, M., Maso, M., Capellacci, S., Accoroni, S., Rene, A., Scardi, M., Penna, A., July 2010. Monitoring toxic microalgae Ostreopsis (dinoflagellate) species in coastal waters of the Mediterranean sea using molecular PCR-based assay combined with light microscopy. Marine Pollution Bulletin 60 (7), 1074-1084.

Beer, S., Spencer, W., Bowes, G., July 1986. Photosynthesis and growth of the filamentous blue-green-alga Lyngbya-birgei in relation to its environment. Journal of Aquatic Plant Management 24, 61-65.

Behets, J., Declerck, P., Delaedt, Y., Verelst, L., Ollevier, F., 2007. A duplex real-time PCR assay for the quantitative detection of Naegleria fowleri in water samples. Water Research 41 (1), 118-126. URL: http://www.sciencedirect.com/science/article/ pii/S0043135406005598.

Bergsland, K.J., Haselkorn, R., 1991. Evolutionary relationships among eubacteria, cyanobacteria, and chloroplasts: evidence from the rpoc 1 gene of Anabaena sp. strain pcc 7120. Journal of Bacteriology 173 (11), 3446-3455. URL: http://jb.asm.org/ content/173/11/3446.abstract.

Cane, D.E., He, X., Kobayashi, S., ömura, S., Ideda, H., 2006. Geosmin biosynthesis in Streptomyces avermitilis. Molecular cloning, expression, and mechanistic study of the germacradienol/geosmin synthase. The Journal of Antibiotics 59 (8), 471-479.

Cane, D.E., Watt, R.M., 2003. Expression and mechanistic analysis of a germacradienol synthase from Streptomyces coelicolor implicated in geosmin biosynthesis. Proceedings of the National Academy of Sciences of the United States of America 100 (4), 1547-1551. URL: http://www.pnas.org/content/100/4/ 1547.abstract.

Christensen, E.R., Kusk, K.O., Nyholm, N., 2009. Dose-response regressions for algal growth and similar continuous endpoints: calculation of effective concentrations. Environmental Toxicology and Chemistry 28 (4), 826-835. URL: http://dx.doi.org/10.1897/08-068R.1.

Colwell, R.K., 2009. Biodiversity: concepts, patterns, and measurement. The Princeton Guide to Ecology, 257-263.

Cramer, M., Myers, J., 1952. Growth and photosynthetic characteristics of euglena gracilis. Archiv für Mikrobiologie 17, 384-402. URL: http://dx.doi.org/10.1007/BF00410835.

Deng, X., Liang, G., Chen, J., Qi, M., Xie, P., 2011. Simultaneous determination of eight common odors in natural water body using automatic purge and trap coupled to gas chromatography with mass spectrometry. Journal of Chromatography A 1218 (24), 3791-3798. URL: http://www. sciencedirect.com/science/article/pii/S0021967311005516.

Fergusson, K.M., Saint, C.P., 2000. Molecular phylogeny of Anabaena circinalis and its identification in environmental samples by PCR. Applied and Environmental Microbiology 66 (9), 4145-4148. URL: http://aem.asm.org/content/66/9/4145. abstract.
Giglio, S., Jiang, J., Saint, C.P.S., Cane, D.E., Monis, P.T., 2008. Isolation and characterization of the gene associated with geosmin production in cyanobacteria. Environmental Science and Technology 42 (21), 8027-8032. URL: http://pubs.acs.org/ doi/abs/10.1021/es801465w.

Giglio, S., Saint, C.P., Monis, P.T., 2011. Expression of the geosmin synthase gene in the cyanobacterium Anabaena circinalis awqc318. Journal of Phycology 47 (6), 1338-1343. URL: http:// dx.doi.org/10.1111/j.1529-8817.2011.01061.x.

Gust, B., Challis, G.L., Fowler, K., Kieser, T., Chater, K.F., 2003. Pcrtargeted Streptomyces gene replacement identifies a protein domain needed for biosynthesis of the sesquiterpene soil odor geosmin. Proceedings of the National Academy of Sciences of the United States of America 100 (4), 1541-1546. URL: http:// www.pnas.org/content/100/4/1541.abstract.

Haas, J.N., 1996. Neorhabdocoela oocytes - palaeoecological indicators found in pollen preparations from holocene freshwater lake sediments. Review of Palaeobotany and Palynology 91 (1-4), 371-382. URL: http://www.sciencedirect. com/science/article/pii/0034666795000747.

Harris, E.H., Stern, D.B., Witman, G.B., 1989. The Chlamydomonas Sourcebook. Cambridge Univ Press.

Hasle, G.R., 1978. In: Sournia, A. (Ed.), Phytoplankton Manual. Unesco, Paris.

Ho, L., Hoefel, D., Bock, F., Saint, C.P., Newcombe, G., 2007. Biodegradation rates of 2-methylisoborneol (mib) and geosmin through sand filters and in bioreactors. Chemosphere 66 (11), 2210-2218. URL: http://www.sciencedirect.com/ science/article/pii/S0045653506011428.

Hotzel, G., Croome, R., 1994. Long-term phytoplankton monitoring of the Darling River at Burtundy, New-South-Wales - incidence and significance of cyanobacterial blooms. Australian Journal of Marine and Freshwater Research 45 (5), 747-759.

Humbert, J., Quiblier, C., Gugger, M., 2010. Molecular approaches for monitoring potentially toxic marine and freshwater phytoplankton species. Analytical and Bioanalytical Chemistry 397, 1723-1732. URL: http://dx.doi.org/10.1007/ s00216-010-3642-7.

Innok, S., Matsumura, M., Boonkerd, N., Teaumroong, N., 2005. Detection of microcystis in lake sediment using molecular genetic techniques. World Journal of Microbiology and Biotechnology 21, 1559-1568. URL: http://dx.doi.org/10.1007/ s11274-005-7893-y.

Jiang, J., He, X., Cane, D.E., 2006. Geosmin biosynthesis. Streptomyces coelicolor germacradienol/germacrene D synthase converts farnesyl diphosphate to geosmin. Journal of the American Chemical Society 128 (25), 8128-8129. URL: http://pubs.acs.org/doi/abs/10.1021/ja062669x.

Jiang, J., He, X., Cane, D.E., 2007. Biosynthesis of the earthy odorant geosmin by a bifunctional Streptomyces coelicolor enzyme. Nature Chemical Biology 3 (11), 711-715.

Koskenniemi, K., Lyra, C., Rajaniemi-Wacklin, P., Jokela, J., Sivonen, K., 2007. Quantitative real-time PCR detection of toxic Nodularia cyanobacteria in the Baltic Sea. Applied and Environmental Microbiology 73 (7), 2173-2179. URL: http:// aem.asm.org/content/73/7/2173.abstract.

Krienitz, L., Ballot, A., Wiegand, C., Kotut, K., Codd, G., Pflugmacher, S., Dec 2002. Cyanotoxin-producing bloom of Anabaena flos-aquae, Anabaena discoidea and Microcystis aeruginosa (Cyanobacteria) in Nyanza Gulf of Lake Victoria, Kenya. Journal of Applied Botany-Angewandte Botanik 76 (5-6), 179-183.

Kuosa, H., 1991. A bloom of the blue-green alga Anabaena lemmermannii-var-minor Nostocophyceae in the Gennarbyviken fresh-water reservoir southern Finland. Memoranda Societatis pro Fauna et Flora Fennica 67, 147-149.

Li, Z., Yu, J., Yang, M., Zhang, J., Burch, M.D., Han, W., 2010. Cyanobacterial population and harmful metabolites dynamics 
during a bloom in Yanghe Reservoir, North China. Harmful Algae 9 (5), 481-488. URL: http://www.sciencedirect.com/ science/article/pii/S1568988310000260.

Liang, C., Wang, D., Yang, M., Sun, W., Zhang, S., 2005. Removal of earthly-must odorants in drinking water by powdered activated carbon. Journal of Environmental Science and Health 40 (4), 767-778.

Llewellyn, L.E., Negri, A.P., Doyle, J., Baker, P.D., Beltran, E.C., Neilan, B.A., 2001. Radioreceptor assays for sensitive detection and quantitation of saxitoxin and its analogues from strains of the freshwater cyanobacterium, Anabaena circinalis. Environmental Science and Technology 35 (7), 1445-1451. URL: http://pubs.acs.org/doi/abs/10.1021/es001575z.

Ludwig, F., Medger, A., Börnick, H., Opitz, M., Lang, K., Göttfert, M., Röske, I., 2007. Identification and expression analyses of putative sesquiterpene synthase genes in Phormidium sp. and prevalence of geoA-like genes in a drinking water reservoir. Applied and Environmental Microbiology 73 (21), 6988-6993. URL: http://aem.asm.org/content/73/21/6988.abstract.

Lylloff, J.E., Mogensen, M.H., Burford, M.A., Schluter, L., Jorgensen, N.O.G., 2012. Detection of aquatic streptomycetes by quantitative PCR for prediction of taste-and-odour episodes in water reservoirs. Journal of Water Supply Research and Technology-Aqua 61 (5), 272-282.

Marbun, Y.R., Yen, H.-K., Lin, T.-F., Lin, H.-L., Michinaka, A., 2012. Rapid on-site monitoring of cylindrospermopsin-producers in reservoirs using quantitative PCR. Sustainable Environment Research 22 (3), 143-151.

Matsunaga, T., Takeyama, H., Nakayama, H., 2001. 16s rRNAtargeted identification of cyanobacterial genera using oligonucleotide-probes immobilized on bacterial magnetic particles. Journal of Applied Phycology 13, 389-394. URL: http://dx.doi.org/10.1023/A\%3A1017990518648.

Morales, E.A., 2005. Observations of the morphology of some known and new fragilarioid diatoms (Bacillariophyceae) from rivers in the USA. Phycological Research 53 (2), 113-133. URL: http://dx.doi.org/10.1111/j.1440-183.2005.00378.x.

Moustafa, A., Beszteri, B., Maier, U.G., Bowler, C., Valentin, K., Bhattacharya, D., 2009. Genomic footprints of a cryptic plastid Endosymbiosis in diatoms. Science 324 (5935), 1724-1726. URL: http://www.sciencemag.org/content/324/5935/1724.abstract.

Orsini, M., Romano-Spica, V., 2001. A microwave-based method for nucleic acid isolation from environmental samples. Letters in Applied Microbiology 33 (1), 17-20. URL: http://dx.doi.org/ 10.1046/j.1472-765X.2001.00938.x.

Palenik, B., Haselkorn, R., Jan 16 1992. Multiple evolutionary origins of prochlorophytes, the chlorophyll B-containing prokaryotes. Nature 355 (6357), 265-267.

Pan, X., Chang, F., Liu, Y., Li, D., Xu, A., Shen, Y., Huang, Z., 2009. Mouse toxicity of Anabaena flos-aquae from lake Dianchi, China. Environmental Toxicology 24 (1), 10-18. URL: http://dx. doi.org/10.1002/tox.20385.

Provasoli, L., McLaughlin, J., Droop, M., 1957. The development of artificial media for marine algae. Archiv für Mikrobiologie 25, 392-428. URL: http://dx.doi.org/10.1007/BF00446694.

R Development Core Team, 2011. R: A Language and Environment for Statistical Computing. R Foundation for Statistical Computing, Vienna, Austria, ISBN 3-900051-07-0. URL: http:// www.R-project.org/.

Rasmussen, J., Barbez, P., Burgoyne, L., Saint, C., 2008a. Rapid preparation of cyanobacterial DNA for real-time PCR analysis. Letters in Applied Microbiology 46 (1), 14-19. URL: http://dx. doi.org/10.1111/j.1472-765X.2007.02252.x.

Rasmussen, J., Giglio, S., Monis, P., Campbell, R., Saint, C., 2008b. Development and field testing of a real-time PCR assay for cylindrospermopsin-producing cyanobacteria. Journal of Applied Microbiology 104 (5), 1503-1515. URL: http://dx.doi. org/10.1111/j.1365-2672.2007.03676.x.
Rasmussen, J., Saint, C., Monis, P., 2007. Use of Dna melting simulation software for in silico diagnostic assay design: targeting regions with complex melting curves and confirmation by real-time PCR using intercalating dyes. BMC Bioinformatics 8 (1), 107. URL: http://www.biomedcentral. com/1471-2105/8/107.

Rinta-Kanto, J.M., Ouellette, A.J.A., Boyer, G.L., Twiss, M.R., Bridgeman, T.B., Wilhelm, S.W., 2005. Quantification of toxic Microcystis spp. during the 2003 and 2004 blooms in western lake erie using quantitative real-time PCR. Environmental Science and Technology 39 (11), 4198-4205. URL: http://pubs. acs.org/doi/abs/10.1021/es048249u.

Rippka, R., Deruelles, J., Waterbury, J.B., Herdman, M., Stanier, R.Y., 1979. Generic assignments, strain histories and properties of pure cultures of cyanobacteria. Journal of General Microbiology 111 (1), 1-61. URL: http://mic. sgmjournals.org/content/111/1/1.abstract.

Ririe, K.M., Rasmussen, R.P., Wittwer, C.T., 1997. Product differentiation by analysis of DNA melting curves during the polymerase chain reaction. Analytical Biochemistry 245 (2), 154-160. URL: http://www.sciencedirect.com/science/article/ pii/S0003269796999169.

Rocap, G., Distel, D.L., Waterbury, J.B., Chisholm, S.W., 2002. Resolution of Prochlorococcus and Synechococcus ecotypes by using 16s-23s ribosomal DNA internal transcribed spacer sequences. Applied and Environmental Microbiology 68 (3), 1180-1191. URL: http://aem.asm.org/content/68/3/1180.abstract.

Rodenacker, K., Gais, P., Jutting, U., Hense, B.A., 2001. (Semi-) automatic recognition of microorganisms in water. In: IEEE, 345 E 47TH ST, NEW YORK, NY 10017 USA, International Conference on Image Processing (ICIP 2001), Thessaloniki, Greece, OCT 07-10, 2001.

Saadoun, I., Schrader, K.K., Blevins, W.T., 2001. Identification of geosmin as a volatile metabolite of Anabaena sp. Journal of Basi Microbiology 41 (1), 51-55.

Sabour, B., Loudiki, M., Oudra, B., Vasconcelos, V., Oubraim, S., Fawzi, B., 2005. Dynamics and toxicity of Anabaena aphanizomenoides (cyanobacteria) waterblooms in the shallow brackish Oued Mellah lake (morocco). Aquatic Ecosystem Health \& Management 8 (1), 95-104.

Shannon, C.E., Weaver, W., Blahut, R.E., Hajek, B., 1949. The Mathematical Theory of Communication, vol. 117. University of Illinois press, Urbana.

Sherr, E., Sherr, B., 1993. Preservation and storage of samples for enumeration of heterotrophic protists. In: Handbook of Methods in Aquatic Microbial Ecology. Lewis Publishers, Boca Raton, pp. 207-212.

Sotero-Santos, R.B., Carvalho, E.G., Dellamano-Oliveira, M.J., Rocha, O., 2008. Occurrence and toxicity of an Anabaena bloom in a tropical reservoir (southeast brazil). Harmful Algae 7 (5), 590-598. URL: http://www.sciencedirect.com/science/article/ pii/S156898830700193X.

Steindler, L., Huchon, D., Avni, A., Ilan, M., 2005. 16s rRNA phylogeny of sponge-associated cyanobacteria. Applied and Environmental Microbiology 71 (7), 4127-4131. URL: http:// aem.asm.org/content/71/7/4127.abstract.

Wu, J.-T., Jüttner, F., 1988. Differential partitioning of geosmin and 2-methylisoborneol between cellular constituents in Oscillatoria tenuis. Archives of Microbiology 150, 580-583. URL: http://dx.doi.org/10.1007/BF00408253.

Xie, W.Q., Jäger, K., Potts, M., 1989. Cyanobacterial rna polymerase genes rpoc 1 and rpoc 2 correspond to rpoc of Escherichia coli. Journal of Bacteriology 171 (4), 1967-1973. URL: http://jb.asm.org/content/171/4/1967.abstract.

Zhang, T., Li, L., Song, L., Chen, W., 2009. Effects of temperature and light on the growth and geosmin production of Lyngbya kuetzingii (Cyanophyta). Journal of Applied Phycology 21, 279-285. URL: http://dx.doi.org/10.1007/s10811-008-9363-z. 